\title{
Impact of climate change on food value of molluses in Nepal
}

\author{
Bharat Raj Subba \\ Department of Zoology, Post Graduate Campus, Tribhuvan University, Biratnagar, Nepal \\ E-mail: subbabharat@yahoo.com
}

\begin{abstract}
The questionnaires and interviews were taken randomly with ethnic people, the molluscs consumers of different districts of Tarai regions. Regarding other information about the impact of climate change in the context of Nepal, literature survey was done. Edible molluscs are cheap non-conventional source of protein for huge population of poor ethnic peoples (53 castes living in twenty districts of Tarai in Nepal), from time immemorial. Up to, nearly four and half decades back, there were virgin forests in Tarai region, water sources were in better condition but because of rapid population explosion, encroachment of wetlands and deforestation the water sources began to dry up early in the year. Gradual increase in atmospheric temperature due to imbalanced amount of $\mathrm{CO}_{2}$ and precipitation, is worsening the environment. The climate change is not only destroying the suitable aquatic environment of the molluscs habitats but their foods of plant and animal origins as well. Several changes in water chemistry might have taken place threatening aquatic lives including molluscs. As a result, annual production of mollusc also has decreased. The climate change is enforcing molluscs to change their original habitats and habits. While their production of molluscs is decreasing, demand is increasing due to rapid human population growth. The price of molluscs meat also has increased $100 \%$ as compared to one decade back (Bellamya Rs 20-25/kg with shell, Pila without shell Rs 48-60/kg, similarly bivalves (Lamellidens and Parreysia) Rs 20-30/kg with shell whereas Rs 50-60/kg without shell; Brotia Rs $10-12 / \mathrm{kg}$ with shell). Local production of Nepal covers hardly $30-40 \%$ demand of molluscs. The rest $60 \%$ demand is met imported from India. The only solution of the problem is to initiate molluscs culture which will also help conserve water sources and other aquatic organisms as well.
\end{abstract}

Key words: Climate change, mollusca, food value, Nepal

\section{Introduction}

Nepal is geographically isolated from marine environment. Freshwater bodies such as rivers, lakes, reservoirs, marshy lands, seasonal or perennial wetlands (streams, rivulets, ponds, pits, pools) are the habitats of aquatic molluscs.

Molluscs are soft bodied invertebrates found in both land and water. They are most abundant next to arthropods and are widely distributed. Different climatic regions of Nepal are suitable habitats for 70 species of molluscs. They have been recorded from 65 to $4800 \mathrm{~m}$ altitudes in Nepal. But edible aquatic molluscs are found only in Tarai region and valleys of 
the country. Fifty aquatic species of molluscs have been reported from Nepal till now, out of them, 25 species are consumed my ethnic people (Subb \& Ghosh, 2000). Ethnic people consume molluscs meat as one of the delicious and energy giving food items. In Nepal molluscs consumers depend on the natural production of molluscs only. Since three and half decades onward, natural production of molluscs has been decreasing as per consumer's statement. The local natural production of molluscs hardly meets consumers demand for three to four months in year, after that there appears shortage of molluscs. It has happened because most of the seasonal as well as perennial water sources begin to dry up soon just after monsoon is over. The main reason is the impact of climate change which comprises unpredictable rainfall, global warming, and threatening biodiversity of any region of the world. The impact of climate change is common to all living beings but for slow- moving animals like molluscs, it seems more serious. As emerging and hibernating time of different animals have got their own schedule from time immemorial, so it is not easy to change that time with the change in climate. In this way, along with early drying up of water bodies, several larvae of molluscs die. Similarly with irregular monsoon, long drought killed hibernating molluscs. Shallow water when gets heated becomes unsuitable environment for the molluscs to exist. Climate change is impacting on the production of molluscs in many folds ways. Western part of Nepal receives comparatively less rainfalls than eastern but population of molluscs consumers, the ethnic poor people are more in the west and far west than in the east. A new challenge being created by climate change is emerging out for molluscs consumers because they are being forced to change their dependency on molluscs a non conventional source of animal protein on one hand, their income sources are limited to afford to purchase so called market readymade meat, source of protein and fat on the other. The balanced diet of vegetable origin is widely reckoned to be insufficient to provide a complete dietary balance, in terms of essential aminoacids (Shakya \& Mishra, 2008).

Wetlands are the important habitat for aquatic molluscs. In Nepal, lotic environment covers an area of about 3,95,000 ha whereas 3,50,00 ha of wetland has lentic environment (FDD, 1992). The highest number of wetland sites is represented by lakes and ponds (48\%) followed by riverine floodplain $(33 \%)$ in Nepal. But wetlands are disappearing fast because of human encroachment, natural succession and climate change. Wetlands are expected to have provided shelter to more than 50 molluscan species in Nepal.

Himalayan region as a whole is rich in molluscs, harboring $52.2 \%$ of the terrestrial species and $47.8 \%$ of the freshwater species in the eastern and central Himalayas (Dey \& Mitra, 2000). Subba Rao (1989) reported 285 species of freshwater molluscs collected from India, Pakistan, Bangladesh, Myanmar, Sri-Lanka and other adjoining countries. Some 50 species of aquatic molluscs are found in Nepal. Nesemann and Sharma (2003) have reported existence of 45 species of aquatic molluscs (25 gastropods and 20 bivalves) from lowland (Tarai) regions of Nepal. Other notable contributions on molluscan species of Nepal have been made by Kuznetsov (1996), Schileyko and Kuznetsov (1996), Kuznetsov and Schileyko (1997), Subba and Ghosh (2000), Subba (2003), Subba et al. (2004), Buddha (2005) and Subba and Pandey (2005).

\section{Nutritional value of mollusc}

There are few comprehensive data available, but some reviews confirm the generally held view that mollusc meat is high in protein and low in fat, with the majority of the fats in the 
form of polyunsaturated. Most molluscs (e.g., snails) can be a fairly labor intensive food source, because in addition to collection, they must be purged before being consumed (Lubell, 2007).

According to Misra et al. (2002) the main fatty acid components in Bellamya bengalensis and Pila globosa consist of saturated fatty acids (48-60\%), monoenic (18-30\%), and polyunsaturates (21-33\%). Polyunsaturated fatty acids (PUFAs) have great dietary importance because these include what is commonly known as 'essential fatty acids' (consisting of linoleic-, linolenic-, and arachidonic acid). Consumption of these molluscs can therefore help fulfill part of the dietary requirement for essential fatty acids.

Authentic data on the nutritional value of edible molluscs of Nepal is relatively scant. Karna and Shrestha (2006) have studied the nutritional value of three mollusc species (Bellamya bengalensis, Lamellidens marginalis and Pila globosa) of Sarlahi district of Nepal (Tab. 1). The authors consider molluscs as the cheapest source of animal protein ever known. This statement probably has only contextual implication. The nutritional value of molluscs of other regions of the world has been mentioned by different workers (Meric et al., 1991; Misra et al., 2002; Ponis et al., 2006; Gebhardt \& Thomas, 2002; Fagbuaro et al., 2006; Subba et al., 2009).

Table 1. Nutritional components of some edible molluscs of Nepal.

\begin{tabular}{lccc}
\hline \multirow{2}{*}{ Parameter } & \multicolumn{3}{c}{ Snail species } \\
\cline { 2 - 4 } & $\begin{array}{c}\text { Bellamya } \\
\text { bengalensis }\end{array}$ & $\begin{array}{c}\text { Lamellidens } \\
\text { marginalis }\end{array}$ & Pila globosa \\
\hline Moisture (\%) & 5.84 & 5.11 & 5.61 \\
Protein (\%) & 57.46 & 52.59 & 60.52 \\
Fat (\%) & 5.48 & 4.34 & 5.69 \\
Fiber (\%) & 0.19 & 0.66 & 0.50 \\
Carbohydrates (\%) & 14.63 & 20.24 & 17.68 \\
Ash (\%) & 16.37 & 17.0 & 10.0 \\
Calcium (\%) & 8.71 & 4.86 & 3.47 \\
Phosphorus (\%) & 0.56 & 2.75 & 0.92 \\
Energy (kcal/100g) & 337.68 & 330.38 & 364.01 \\
\hline
\end{tabular}

Source: Karna \& Shrestha (2006).

\section{Climate change in Nepal}

Nepal has wide variation of climates from subtropical warm in the south, cool in the hills to cold in the mountains within a horizontal distance of less than $200 \mathrm{~km}$ (Shankar \& Shrestha, 1985; Chalise, 1994; UNDP, 2001). The climate of Nepal is dominated by monsoon about $80 \%$ of annual precipitation occurs during the summer monsoon (UNDP, 2001). The amount of precipitation varies from place to place because of non-unifom rugged terrain (Shankar \& Shrestha, 1985). However, the amount of rainfall generally declines from east to west (UNEP, 2001). The length of the regular and systematic observations of climatological and 
hydrological data in Nepal is only about 50 years (Mool et al., 2001). The longest systematic temperature and precipitation data have been available for Kathmandu since 1921 recorded by the then-Indian Embassy under British rule (Shrestha et al., 1999). The existing climatological and hydrological stations are generally located at the lower elevations. The high mountain areas with very low population density and negligible economic activities are mostly left without any hydrological and meteorological stations. So, even the available climatic data are also very scarce, poorly representing the high mountain areas. The meteorological 14 observations in high mountain areas were only initiated in 1987 after the establishment of the Snow and Glacier Hydrology Section in the Department of Hydrology and Meteorology of Nepal (Mool et al., 2001).

\section{Change in temperature}

The oldest temperature records available so far for Kathmandu and its surroundings were documented by Hamilton during his stay in Nepal from April, 1802 to March, 1803, but this information does not provide the information on site and equipment of measurement (Chalise, 1994). There is no continuous temperature record at all for the subsequent years up to 1921. The studies on analyses of the temperature records of Kathmandu for the period of 1921-1994 showed a similar temperature trend as that of $24-40^{\circ} \mathrm{C}$ of the earth, i.e., a general warming trend till 1940s, a cooling trend during 1940-1970s and a rapid warming after the mid 1970s (Shrestha et al., 1999; Shrestha, 2001). Sharma et al. (2000) indicated that the increasing trend of average temperatures during that period was primarily due to the increasing trend in maximum temperature and there was no increasing trend in minimum temperature. The temperature trends for 1971-1994 as analysed by Shrestha et al. (1999) widely varied among the geographical regions and the seasons in Nepal. Low-elevation areas in the south showed a slower warming rate than the high mountain areas in the north. Average annual temperatures in the Tarai regions in the south increased by about $0.04^{\circ} \mathrm{C} / \mathrm{yr}$, whereas those in the middle mountain areas in the north increased by about $0.08^{\circ} \mathrm{C} / \mathrm{yr}$.

Similarly, the pre-monsoon season (March-May) showed the lowest warming rate of $0.03^{\circ} \mathrm{C} / \mathrm{yr}$, while the post-monsoon season (October-November) showed the highest one of $0.08^{\circ} \mathrm{C} / \mathrm{yr}$ (Shrestha, 2001).

\section{Change in precipitation}

Shrestha et al. (2000) reported that there was no distinct long-term trend in the precipitation records in Nepal during 1948-1994, though there was significant variation on annual and decade time scales. The same study revealed that there was a strong relationship between all-Nepal monsoon precipitation and the El-Nino- Southern oscillation. However, Sharma et al. (2000) found an increasing trend in observed precipitation data from Koshi Basin in eastern Nepal but the trend widely varied in seasons and in sites. The precipitation fluctuation in Nepal is not the same as the all-India precipitation trend; but it is well related with rainfall variations over northern India (Shrestha et al., 2000). Similarly, in Asia, monsoon had a significant connection with the El-Nino- Southern Oscillation. Another study based on the precipitation records from 80 stations for the period 1981-1998 across Nepal revealed that the hills and mountains in the north showed positive trends while the plains in the south were experiencing negative trends (MOPE, 2004). 


\section{Statement of the problem}

The state of food insecurity in Nepal has been persistently worsening in the recent years. During 2006, World Food Program (WFP) estimated that $47 \%$ of the population of Nepal is chronically hungry. Experts are of the view that solution to this problem lies, among other things, in the development of a sustainable food system or conserving natural food availability from the impact of climate change otherwise, poor people will suffer from nutrition deficiency diseases as well. The problem here is how the climate change is impacting on the food value of molluscs. Edible molluscs are consumed in significant amounts by certain ethnic groups (more than 30 castes) of Tarai only (Subba \& Ghosh, 2000). Molluscs are conventional source of protein, fat and other nutrients.

\section{Study sites}

\section{Tarai}

It is a northern limit of Indo-Gangetic plain with narrow strip of relatively flat area of about $192 \mathrm{~km}$ east (Mechi river) to west (Kamala river) long and 16 to $40 \mathrm{~km}$ wide, between Siwalik and southern frontier of Nepal, covers $17 \%$ of total area of the country (Fig. 1). It has sub-tropical hot and humid monsoon climate with hot and wet summers and cool and dry winters. The mean temperature, annual rainfall, and relative humidity are $25^{\circ} \mathrm{C}, 2169.5 \mathrm{~mm}$, and around $74.4 \%$, respectively. Tarai can be divided into three zones: (a) Southern Tarai, (b) Middle Tarai, and (c) Bhabar.

$80^{\circ}$

$82^{\circ}$

$84^{\circ}$

$86^{\circ}$

$88^{\circ}$

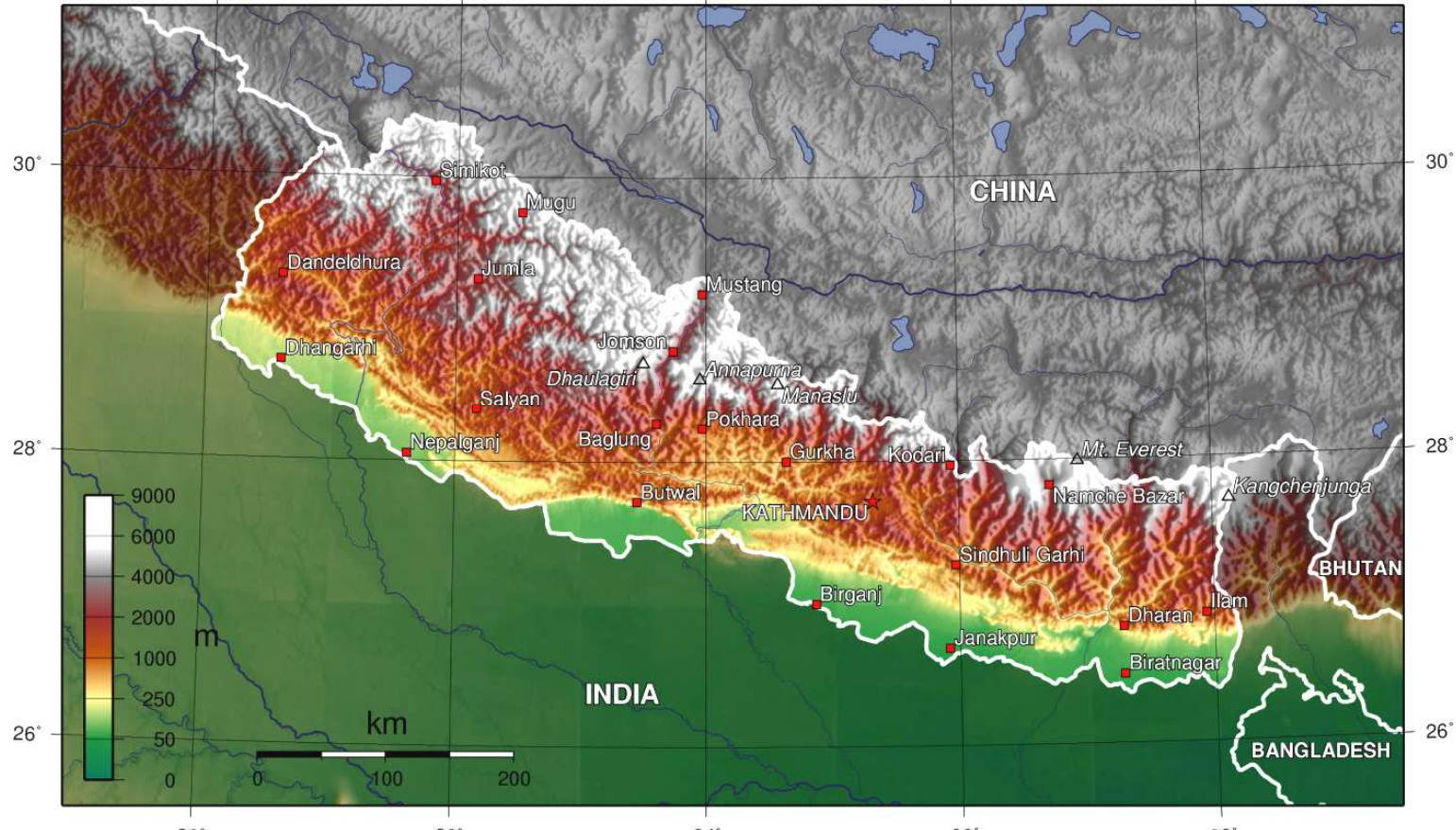

Figure 1. Satellite map of Nepal.

Middle Tarai, between Southern Tarai and Bhabar consists of swampy and marshy lands with numerous old ox-bow lakes and ponds. This area is highly productive and rich in ground water resources, thus the human encroachment has converted dense forests into 
cultivated lands of several places such as Kakadvitta, Dhulabari, Birtamod, Damak, Urlabari, Itahari, Inaruwa, Biratnagar, Lahan, Janakpur, Lumbini, Bhairhawa, Kailali, Kachanpur, Bardiya, Kailali and so on.

Bhabar zone lies immediately at the foot of the Siwalik hills and consists of bouldery and gravelly areas derived by alluvial fans from Mahabharat and Churia ranges. Places like Budhabare, Madhumalla, Letang, Kerabari, Dharan, Chatara, Gaighat, Fattepur are located in this zone.

\section{Materials and Methods}

Literature surveys, questionnaires, direct interviews with ethnic peoples who consume molluscs, visiting different districts of Tarai from east to west were performed. Observations of habitats of molluscs and local markets where moilluscs are sold were made. Available data related to the present study were gathered from various sources. The present study was performed taking especially the case of the impact of climate change on food value of molluscs in twenty districts of Nepal namely Jhapa, Morang, Sunsari, Saptari, Siraha, Dhanusa, Sarlahi, Rautahat, Mahotari, Rupandehi, Bara, Parsa, Chitwan, Kanchanpur, Nawalparasi, Rautahat, Dang, Banke. Bardia and Kailali where edible mollucs are found

\section{Results}

Subba and Ghosh (2000) have reported that 20 edible species out of 50 aquatic species of molluscs. The ethnic people of the Tarai Nepal consume molluscs with relish. It has been estimated that more than $70 \%$ people belong to the ethnic communities in Tarai. In spite of huge number of consumers, the production of edible molluscs in Nepal was found negligible as mollusca culture has not been started in Nepal yet. Wetlands, the habitats of molluscs, are also fast disappearing because of climate change and population explosion.

Every year significant quantities of edible molluscs are harvested by ethnic communities of Tarai. But at present people belonging to other communities are also beginning to appreciate the taste of molluscan meat. Thus demand for mollusks is increasing but the impact of the climate is decreasing annual product remarkably.

\section{Edible molluscs}

Out of fifty aquatic molluscs reported from Nepal, twenty species via, Pila (2 spp.), Bellamya (3 spp.), Brotia (1sp.), Lamellidens (4 spp.), Parreysia (9 spp.) and Peludomus (1 sp.) which are found in Tarai water bodies are consumed by ethnic peoples of low income, living in Tarai.

\section{Molluscs consumers}

So far information collected from interviews and questionnaires is concerned, more than 56 castes living in Tarai consume molluscs. In Tarai, Bantar, Santhal, Chamar, Sattar, Sudhi, Dhimal, Kumal, Tharu, Rajbanshi, Kurmi, Nuniya, Bhediyar, Hazam, Tatma, Jhangar (also spelt Jhagad), Kewat, Kalwar, Dom, Barai, Tajpuriya, Majhi, Dhanuk, Kamar, Danuwar, Dusadh/Paswan, Gangai, Mushahar, Bangali, Dhobi, Malaha, Sardar, Nurag, Binda, Rajbhar, Lodha, Munda, Khatwe, Dhuniya, Halkhor, Chidimar, Lohar, Kanu, Mallaha, Dusad and some other castes also do consume sometimes. The population of molluscs 
consumers comes to be $25 \%-30 \%$ of the total population of Tarai. According to the census of 2001, the population of Tarai is 11212453 i.e., $48.4 \%$ of the total population of the nation.
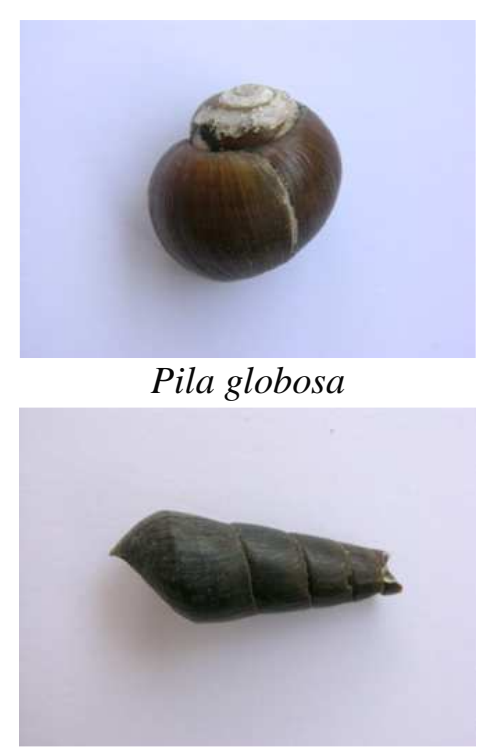

Brotia costula

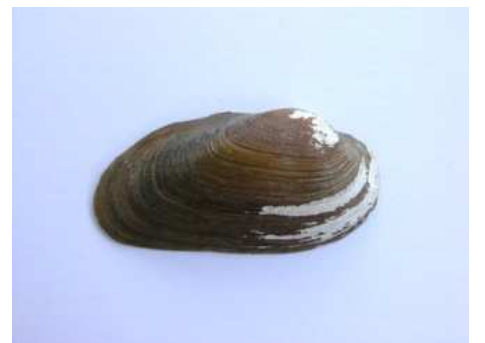

Lamellidens marginalis

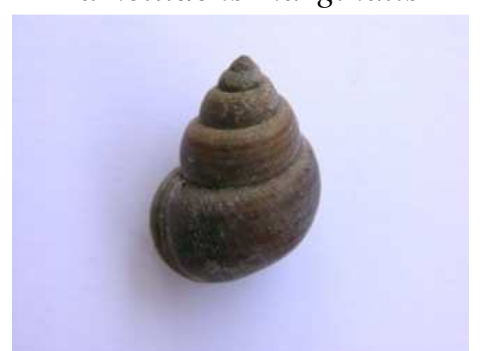

Bellamya bengalensis

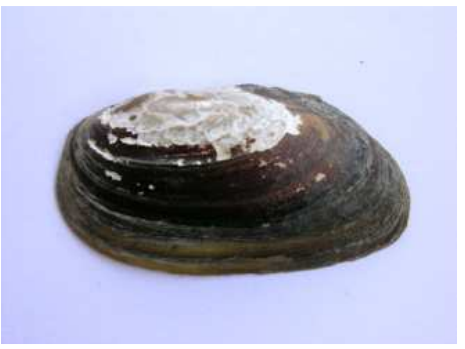

Parreysia sp.

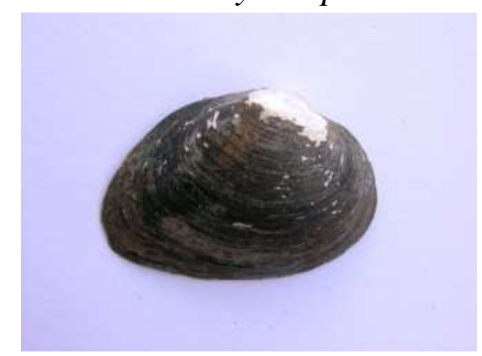

Parreysia sp.

Figure 2. Some edible freshwater molluscs of Nepal.

Because of climate change the water bodies dry up early which does not support the growth of molluscs resulting decrease in annual production. The unpredictable rainfall, draught, deforestation, less precipitation, imbalance $\mathrm{CO}_{2}$ in the atmosphere are likely to be major causes of decrease of molluscs on one hand, consumers population is exploding along with poverty on the other.

From the questionnaires, interviews and literature surveyed it was found that edible molluscs are sold throughout the year. November to January is considered as a peak season in terms of selling. Only small amounts of mollusc are sold in the rest of the months.

Table 2. Total sale of edible molluscs of randomly selected ten districts of Nepal from east to west.

\begin{tabular}{lllcc}
\hline \multirow{2}{*}{ SN Mollusc } & \multirow{2}{*}{ Cost (NRs/kg) } & \multicolumn{2}{c}{ Sale (Quintals) } \\
\cline { 3 - 4 } & & Daily & Monthly \\
\hline 1 & Bellamya bengalensis & $30-50$ & $1.5-2.0$ & $40-60$ \\
2 & Pila globosa & $40-55$ & $2.0-2.5$ & $60-70$ \\
3 & Lamellidens marginalis & $30-40$ with shell, & $2-3$ & $60-80$ \\
& 80-100 without shell & -do- & -do- \\
\hline
\end{tabular}

Table 2 shows the sales volume (daily and monthly) of edible molluscs and its cost in local market of some districts from east to far west of Nepal. Jhapa, Morang, Sunsari, Saptary, Dhanusa, Siraha, Chitwan, Badia, Dang, Kailali districts. The estimated, the monthly sale in particular, is rather conservative because of wide monthly variation of sales volume.

However, the market price and quantity of the molluscs fluctuate from season to season and place to place but in average the price has been rising (Source: respondants). 


\section{Nutritional values}

Table 3 shows the composition of meat compostion of three species of molluscs Bellamya bengalensis, Lamellidens marginalis and Pila globosa

Table 3. Summary of LSD test for difference in food value of Bellamya bengalensis, Lamellidens marginalis and Pila globosa.

\begin{tabular}{lcccc}
\hline \multirow{2}{*}{$\begin{array}{l}\text { Nutrient } \\
\text { composition }\end{array}$} & $\begin{array}{c}\text { Bellamya } \\
\text { bengalensis }\end{array}$ & $\begin{array}{c}\text { Lamellidens } \\
\text { marginalis }\end{array}$ & Pila globosa & $\begin{array}{c}\text { LSD } \\
(5 \%)\end{array}$ \\
\cline { 2 - 4 } Moisture, \% (wb) & $74.17^{\mathrm{a}} \pm 1.05$ & $72.57^{\mathrm{a}} \pm 2.07$ & $71.61^{\mathrm{a}} \pm 1.89$ & 4.502 \\
Protein, \% (wbf) & $17.27^{\mathrm{a}} \pm 0.71$ & $13.39^{\mathrm{b}} \pm 1.09$ & $15.83^{\mathrm{ab}} \pm 1.03$ & 2.526 \\
Fat, \% (wbf) & $3.13^{\mathrm{a}} \pm 0.13$ & $4.71^{\mathrm{b}} \pm 0.36$ & $4.80^{\mathrm{b}} \pm 0.32$ & 0.728 \\
$\mathrm{Ash}, \%$ (wbf) & $3.69^{\mathrm{a}} \pm 0.14$ & $7.68^{\mathrm{b}} \pm 0.56$ & $5.49^{\mathrm{c}} \pm 0.37$ & 0.959 \\
$\mathrm{Ca}, \mathrm{mg} / 100 \mathrm{~g}(\mathrm{wbf})$ & $1505.09^{\mathrm{a}} \pm 61.22$ & $2130.54^{\mathrm{b}} \pm 160.45$ & $1369.42^{\mathrm{a}} \pm 91.32$ & 285.0 \\
$\mathrm{Fe}, \mathrm{mg} / 100 \mathrm{~g}(\mathrm{wbf})$ & $8.56^{\mathrm{a}} \pm 0.35$ & $98.75^{\mathrm{b}} \pm 7.44$ & $25.98^{\mathrm{c}} \pm 1.73$ & 10.23 \\
$\mathrm{~K}, \mathrm{mg} / 100 \mathrm{~g}(\mathrm{wbf})$ & $1.14^{\mathrm{a}} \pm 0.05$ & $0.33^{\mathrm{b}} \pm 0.03$ & $3.50^{\mathrm{c}} \pm 0.23$ & 0.3380 \\
$\mathrm{Na}, \mathrm{mg} / 100 \mathrm{~g}(\mathrm{wbf})$ & $12.32^{\mathrm{a}} \pm 0.50$ & $2.49^{\mathrm{b}} \pm 0.19$ & $13.38^{\mathrm{a}} \pm 0.89$ & 1.621 \\
\hline & & \multicolumn{3}{c}{ Source: Subba et al. $(2009)}$.
\end{tabular}

\section{Impact of climate change on molluscs}

From questionnaires and direct interviews with several local people of Tarai regions of Nepal with special reference to molluscs consumers, it was known that unpredictable rainy season, irregular rainfall, sometime appearance of long draught, deforestation are the major causes of water scarcity in wetlands. These types of events usually occur throughout the country, but, mostly western Nepal is affected more than eastern. This trend has been seen more frequently in the last two decades onward.

\section{Discussion}

As there is no previous published record on the impact of climate change on food value of molluscs of Nepal, to make a discussion on this topic may be unjustifiable. However, respondents' responses can be taken as proofs to reach the conclusion of the study. According to molluscs consumers the natural production has decreased within two decades. They said that in the past, wetlands could support the molluscs growth throughout the year but now most of the wetlands contain water for a few months only in the year. According to them some time it does not rain for a long time, so water level in ponds, pool, rivers decreases in such a way that in some place man-made and natural ponds completely dry up or insufficient water remain so that no aquatic organisms including molluscs can survive there. It has been happening since last three decades. Perhaps the main cause of the declination of the production of the molluscs is the impact of climate change. Less production of edible molluscs has been a new challenge for poor ethnic people now. In the past they at least could get molluscs in wetlands and consumed whenever they willed and were able to fight against the protein and other nutrient deficiency diseases. In some places where production is less but number of consumers is high, there meat of Pila is sold (NC) Rs $200-250 / \mathrm{kg}$. Where there is high demand and less production, the price has increased,so 
there low-incomed ethnic people seem to have been debarred from their easy access to natural food. In the far west districts Kailali, Kanchanpur consumers collect molluscs for three to four months then there is scarcity. They have to wait for next season to come as there mollusc is not imported from other places.

\section{Conclusions}

The followings are the some of the conclusive points of the paper:

- Twenty species of edible molluscs are consumed by ethnic people living in Tetai of Nepal.

- Because of deforestation,encroachment of wetlands, population explosion, uses of chemical fertilizers, insecticides and increase in vehicles number and that of industries, have definitely changed the climate and the changed climate resulting in change in global biodiversity .

- The potential victims of climate change seem to be poor people of developing and under developed countries like Nepal. The main impact of change will be on water, food and nutrition. Mollusc is one of the important natural food items of ethnic people in Nepal as well as in other countries.

- Unless mitigating measures for the climate change are not applied in time, the impact caused by the climate change will not decrease normally.

- In the present scenario of the impact of climate change, mollusca culture is only one alternate way to fulfill the demand of mollusca in Nepal.

- Reforestation, public awareness, application of mitigation processes may be some of the solutions to cut down gradually the potential impact of the climate change on food value of molluscs.

- Indigenous knowledge has to be used both to mitigate climate change and halting decline in natural products.

- All sorts of natural products are only used but rarely conserved throughout the world, As long as the existing trend cannot be evaluated by the consumers themselves and the government policy,it is rather difficult to safe guard molluscs in their natural habitats and produce more amount for the consumers to relish.

\section{References}

Chalise, S.R. 1994: Mountain environments and climate change in the Hindu Kush- Himalayas. In: Mountain Environments in Changing Climate (Ed. M. Beniston). London. pp. 382404

Dey, A. \& S.C. Mitra. 2000. Molluscs of the Himalaya. Records of the Zoological Survey of India 98(2): 5-50.

Fagbuaro, O., J.A. Oso, J.B. Edward \& R.F. Ogunleye. 2006. Nutritional status of four species of giant land snails in Nigeria. J. Zhejiang Univ. 7(9): 686-689.

FDD. 1992. Fisheries Development Division. National Fisheries Development Plan, 1992/1993. Department of Agriculture Development, Fisheries Development Division, Kathmandu.

Gebhardt, S.E. \& R.G. Thomas. 2002. Nutritive value of foods. United States Department of Agriculture, Agriculture Research Service, Home and Garden Bulletin No. 72. 
Karna, R.R. \& J. Shrestha. 2006. Molluscs as a cheap source of animal protein in Sarlahi district, Nepal. Nepal Journal of Science and Technology 7: 45-48.

Kuznetsov, A.G. \& A.A. Schileyko. 1997. New data on Enidae (Gastropoda, Pulmonata) of Nepal. Ruthenica 7(2): 133-140

Kuznetsov, A.G. 1996. Himalodiscus aculeatus Kuznetsov, gen. et sp.nov. (Pulmonata, Endodontidae) from Nepal. Ruthenica 5(2): 163-165.

Lubell, D. 2007. Are land snails a signature of the Mesolithic-Neolithic transition? Documenta Praehistorica 31.

Meric, E., M. Sakinc, M. ozdogan \& F. Ackurt. 1991. Molllusc shells found at the Yarimburgaz cave. J. Islamic Acad. Sci. 4(1): 6-9.

Misra, K.K., I. Shkrob, S. Rakshit \& V.M. Dembitsky. 2002. Variability in fatty acids and fatty aldehydes in different organs of two prosobranch gastropod mollusc. Biochemical Syst and Ecol. 30: 749-761.

Mool, P.K., S.R. Bajracharya \& S.P. Joshi. 2001b: Glacial lakes and glacial lake outburst flood events in the Hindu Kush-Himalayan region. In: Global Change and Himalayan Mountains (Ed. K.L. Shrestha). Institute for Development and Innovation, Lalitpur, Nepal. pp. 75-83.

MOPE. 2004. Initial National Communication to the Conference of Parties of the United Nations Framework.

Nesemann, H. \& S. Sharma. 2003. Population dynamics and distribution of the aquatic molluscs (Gastropods, Bivalvia) from Nepal. Paper presented at the International Conference on Himalayan Biodiversity, Kathmandu, Nepal; 2003 February 26-28.

Ponis, E., I. Probert, B. Veron, J.R. Le Coz, M. Mathieu \& R. Robert. 2006. Nutritional value of six Pavlovophyceae for Crassostrea gigas and Pecten maximus larvae. Aquaculture 254(1-4): 544-553.

Schileyko, A.A. \& A.G. Kuznetsov. 1996. A new genus of the Subulinidae (Pulmonata) from Nepal. Ruthenica 5(2): 158-160.

Shakya, P.M. \& A. Mishra. 2008. An overview of meat industry and meat production system in Nepal. Food Wave. NEFTSA publication, pp. 15-18.

Shankar, K. \& P.B. Shrestha. 1985: Climate. In: Nepal-Nature's Paradise: Insight into diverse facets of topography, flora and ecology (Ed. T.C. Majupuria). White Lotus Co. Ltd, Bangkok. pp. 39-44.

Sharma, K.P., C.J. Vorosmarty \& B. Moore III. 2000. Sensitivity of the Himalayan hydrology to land-use and climatic changes. In: Climatic Change. 47, Kluwer Academic Publishers, Dordrecht, the Netherlands. pp.117-139.

Shrestha, A.B. 2001. Tsho Rolpa Glacier Lake: Is it linked to Climate Change? In: Global Change inHimalayan Mountains (Ed. K.L. Shrestha), Proceedings of a scoping workshop, Kathmandu, Nepal, 2-5 October, 2001. pp. 85-95.

Shrestha, A.B., C.P. Wake, J.E Dibb \& P.A. Mayewski. 1999. Maximum temperature trends in the Himalaya and its vicinity: An analysis based on temperature records from Nepal for the period 1971-94. American Meteorological Society. Journal of Climate 12: 27752786.

Shrestha, A.B., C.P. Wake, J.E. Dibb \& P.A. Mayewski. 2000. Precipitation fluctuations in the Nepal Himalaya and its vicinity and relationship with some large scale climatological 
parameters. Royal Meteorological Society. International Journal of Climatology 20: 317-327.

Subba Rao, N.V. 1989. Handbook of freshwater mollusks of India. Zoological Survey of India, Calcutta, India. 289p.

Subba, B., K.P. Limbu \& B.K. Rai. 2009. Food value of edible Molluscs of eastern Nepal. Project Report submitted to National Academy of Science and Technology (NAST), Kathmandu, Nepal. 45p.

Subba, B.R. \& M.R. Pandey. 2005. An inventory of aquatic biodiversity of Upper Mustang, Nepal. Report submitted to King Mahendra Trust for Nature Conservation, ACAP, Upper Mustang Biodiversity Project. 54 p.

Subba, B.R. \& T.K. Ghosh. 2000. Some freshwater molluscs from eastern and central Nepal. $J$. Bombay nat. His. Soc. 97(3): 452-455.

Subba, B.R. 2003. Molluscan checklist of Ghodaghodi Tal area, Kailali district. Our Nature 1: $1-2$.

Subba, B.R., R. Surana \& K.P. Limbu. 2004. Report of molluscs from Chimdi lake (Birju Tal), Sunsari district, Nepal. Our Nature 2: 45-46.

UNEP. 2001. Nepal: State of the Environment 2001. United Nations Environment Programme and International Centre for Integrated Mountain Development, Kathmandu, Nepal. $211 \mathrm{p}$. 